\title{
A Case of Multiple Myeloma Revealed by a Acute Otitis Media in Adults
}

\author{
Samaké Djibril ${ }^{1,}$, , Sidibé Youssouf ${ }^{2}$, Samaké Magara $^{3}$, Cissé Bana ${ }^{4}$, Bathily Moussa ${ }^{5}$, \\ Haidara Abdoul Wahab ${ }^{6}$, Koné Fatogoma Issa ${ }^{7}$, Maïga Youma Mamadou', Konaté Fatoumata ${ }^{1}$, \\ Dara Yatemelou ${ }^{1}$, Traoré Sounkalo ${ }^{8}$, Doumbia-Singaré Kadidiatou ${ }^{7}$, Timbo Samba Karim ${ }^{7}$, \\ Kéïta Mohamed Amadou ${ }^{7}$
}

${ }^{1}$ ENT and Head and Neck Surgery Department, Commune V Reference Health Center, Bamako, Mali

${ }^{2}$ ENT and Head and Neck Surgery Department, CHU Mère-Enfant "Le Luxembourg", Bamako, Mali

${ }^{3}$ Nephrology-Hemodialysis Unit, Kayes Regional Hospital, Kayes, Mali

${ }^{4}$ Rheumatology Unit, Commune V Reference Health Center, Bamako, Mali

${ }^{5}$ Haemato-Oncology Department, CHU Point-G, Bamako, Mali

${ }^{6}$ ENT and Head and Neck Surgery Department, Ségou Regional Hospital, Segou, Mali

${ }^{7}$ ENT and Head and Neck Surgery Department, CHU-Gabriel Touré, Bamako, Mali

${ }^{8}$ Medical Imaging Department, Commune V Reference Health Center, Bamako, Mali

\section{Email address:}

samakedjibi@yahoo.fr (S. Djibril)

${ }^{*}$ Corresponding author

\section{To cite this article:}

Samaké Djibril, Sidibé Youssouf, Samaké Magara, Cissé Bana, Bathily Moussa, Haidara Abdoul Wahab, Koné Fatogoma Issa, Maïga Youma Mamadou, Konaté Fatoumata, Dara Yatemelou, Traoré Sounkalo, Doumbia-Singaré Kadidiatou, Timbo Samba Karim, Kéita Mohamed Amadou. A Case of Multiple Myeloma Revealed by a Acute Otitis Media in Adults. International Journal of Otorhinolaryngology. Vol. 6, No. 1, 2020, pp. 19-22. doi: 10.11648/j.ijo.20200601.15

Received: March 28, 2020; Accepted: June 10, 2020; Published: June 20, 2020

\begin{abstract}
Multiple myeloma or Kahler's disease is a malignant hemopathy characterized by a clonal proliferation of tumor plasma cells that invade the hematopoietic bone marrow. It is often discovered preferentially during spine, pelvis and ribs pain. Kahler's disease are rarely discovered during ENT infections. We report a case of a 58-year-old female patient that we exanimated in our ENT service for acute suppurative otitis media. The remainder of the examination revealed a swelling in the breast and functional impairment of the right upper limb. The maxillofacial CT- scan revealed lytic lacunar images of maxilla and cranial vault. Conventional X-ray displayed a fracture of the right humeral shaft. The positive diagnosis of multiple myeloma was made using bone marrow biopsy that has shown the presence of pathological plasmatic cells proliferation. Furthermore examination such as the plasma protein electrophoresis found hypo-gamma-globulinemia. Analysis of urinary sediment found $\kappa$-like Bence-Jones proteinuria. We provided Biphosphonates and analgesics treatment in addition to that of acute otitis media. Unfortunately, the death occurred six months later before he was able to benefit from a more invasive treatment protocol. This observation shows us that acute otitis media should not be trivialized, as it required a rigorous clinical examination and may surprise us.
\end{abstract}

Keywords: Multiple Myeloma, Acute Otitis Media, Gap in Images

\section{Introduction}

Multiple myeloma (or Kahler's disease) is a malignant hemopathy due to monoclonal plasma tumor cells proliferation in the bone marrow. Tumor plasma cells produce a monoclonal immunoglobulin or a fragment of a monoclonal immunoglobulin (free light chain) that can be detected in the blood and / or urine [1-3]. It represents around $10 \%$ of hematological cancers, which makes it the second most frequent after lymphomas. It incidence increases rapidly 
with age, and men are more often affected than women [4], [5]. It is most often discovered during an assessment of bone pain, anemia, renal failure or hypercalcemia, and rarely $(10 \%)$ after an infectious bacterial episode [4, 6, 7]. Acute otitis media most commonly results from a tubal reaction following nasopharyngeal infection $[8,9]$. And is most often frequent in young child. It is rare in adults [8]. The immune deficiency as in multiple myeloma is a favorable factor $[2,6$, 8]. This immunosuppression in multiple myeloma is the result of an inhibition of the production of normal immunoglobulins and an increase susceptibility to infections [4]. The sensitivity is increased to infections linked to encapsulated germs, such as Streptococcus pneumoniae and Haemophilus influenzae, induced by the accumulation of malignant plasma cells in the bone marrow [2, 6]. The prognosis varies from patient to patient from a few months to several years. Although it remains incurable to this day, multiple Myeloma has seen significant progress in recent years with an improvement in the management of patients [4]. The below case observation highlights a rare discovery of multiple myeloma in acute otitis media.

\section{Observation}

It was a 58-year-old woman, a housewife with no particular medical and surgical history, who consulted us for left otorrhea evolving for three days. Self-medication treatment that included pain relievers, anti-inflammatories and antibiotics was unsuccessful. Otoscopy displayed acute suppurative otitis media. The rest of the examination found a right jugular swelling (Figure 1) evolving for nine months, associated with pain and functional impotence of the right upper limb. The maxillofacial CT- scan showed lacunar, multiple osteolytic on images rounded to the "punch", without a border of peripheral osteocondensation of the maxilla and the cranial vault (Figure 2) suggesting a multiple myeloma. The conventional X-ray showed a right humeral metaphyseal fracture with thickening of the opposite soft tissues (Figure 3). Several other lacunar images were observed at the acromioclavicular level, bilaterally with thinning of the cortices. At the level of the necks, metaphyses and femoral diaphyses with rupture of the cortices was observed. The bone marrow aspiration returned to normal without plasmacytosis. The positive diagnosis of multiple myeloma was made at bone marrow biopsy that displayed pathological plasmatic proliferation. The plasma protein electrophoresis found hypo-gamma-globulinemia at $5.1 \mathrm{~g} / \mathrm{L}$ in favor of a non-secreting type. In the urine sediment analysis, the 24-hour proteinuria was $834 \mathrm{mg}$ with the presence of Bence-Jones protein of the $\kappa$-like at the immunofixation. An albumin-corrected hypercalcemia at $2.66 \mathrm{mmol} / \mathrm{L}$ was found. The complete blood count revealed a normegenerative normocytic normochromic anemia with a hemoglobin level of $9.1 \mathrm{~g} / \mathrm{dL}$ associated with the presence of anisocytosis. Neutrophils and platelets were normal as well as creatinine serum that was $115 \mu \mathrm{mol} / \mathrm{L}$. Probabilistic oral antibiotic therapy with Amoxicillin + Clavulanic acid resulted in rapid healing of otitis. The rest of the care was provided by the hematology department where she benefited from Biphosphonate and analgesic treatment. She was unable to honor the proposed protocol, Alexanian (Melphalan, Prednisone) in the absence of VTD (Velcade, Thalidomide, Dexamethasone). The death occurred six months later before she could receive chemotherapy.

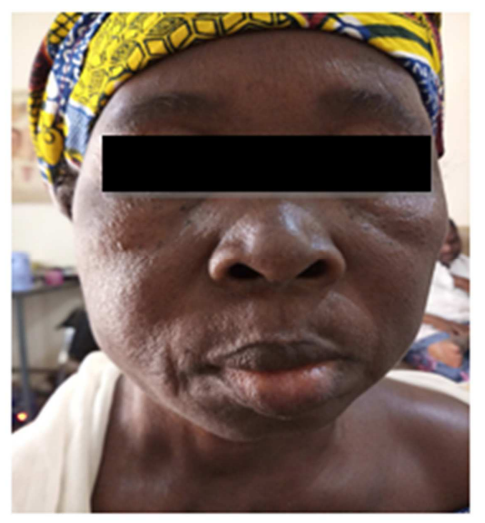

Figure 1. Right jugal swelling

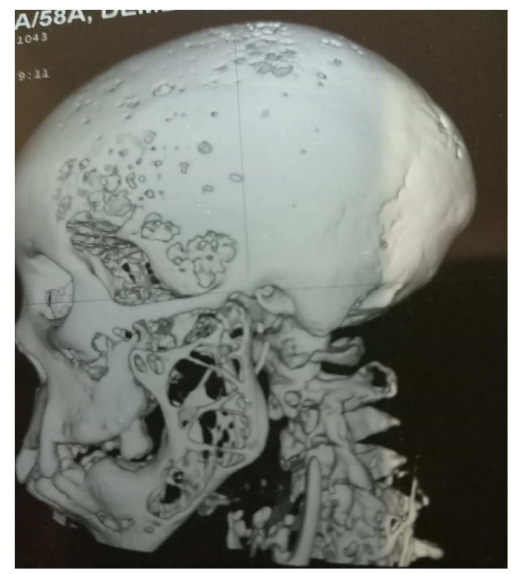

Figure 2. CT scan image of the skull profile showing the lacunar in the maxilla, mandible and cranial vault.

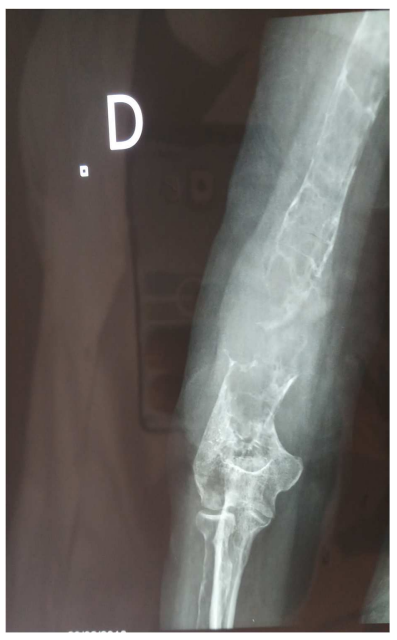

Figure 3. Right humeral conventional X-ray of the face displayed a pathological metaphyseal fracture with multiple lacunar lytic images diffuse with the punch and swelling of the facing soft parts. 


\section{Discussion}

The first well-documented case of multiple myeloma was reported by Samuel Solley in 1844, and the term multiple myeloma was introduced by J. Von Rustizky in 1973 [1]. It most commonly occurs in patients aged from 50 to 80 years with an average age of 60. Multiple myeloma is predominantly found in men $[1,2]$. Its occurrence in adolescents and young adults remains exceptional [4]. In this observation, it was identified in a 58-year-old woman. Its discovery was fortuitous during an acute otitis media with jugale swelling, pain with functional impotence of the right upper limb. Myeloma is often discovered in a context of deterioration of the general state with asthenia, anorexia, weight loss, conjunctival pallor, fever state and bone pain preferentially sitting on the spine, pelvis and ribs. This pain is inflammatory, insomnia that rebellious to the usual painkillers. It is more rarely of the mechanical type. Spinal cord compression or radiculalgia can be seen in some cases. They are related to vertebral compression or tumor compression. One can also meet localized swellings. A pathological fracture can also be revealing of multiple myeloma [2]. The otorrhea which constituted the reason for consultation in our patient is favored on the one hand, by the low socio-economic level leading to self-medication thus delaying the medical consultation. It is made of analgesics, anti-inflammatory drugs and antibiotics, which are often misbehaved in relation to the severity of the clinical picture and the germs involved in these infections. Pneumococcus is one of the germs frequently found in acute otitis media [9, 10]. However, immunity mainly developed against Pneumococcus is compromised in multiple myeloma patients $[6,9,10]$. Indeed, patients with myeloma have a high risk of infection due to an impairment of specific humoral immunity. This phenomenon is linked to the inability to produce specific antibodies due to hypogammaglobulinemia associated with the secretion of a monoclonal protein as in our case [2, 6]. Ionizing radiation recognized as a risk factor for multiple myeloma was not identified in our patient. There are family cases, discussing genetic factors, and cases in spouses, arguing for the importance of environmental factors $[4,11]$. Physiopathogenically, this is a proliferation of plasma cells with initial damage to the bone marrow of the axial skeleton and flat bones. This abnormal proliferation results in osteolytic lesions by the production of osteoclastic substances and inhibitors of osteoblast activity. This cellular hyperactivity led to bone destruction and hypercalcemia which is due to the mobilization of reserves from the osteolytic areas $[2,12,13]$. In the present case, a slight albumin-corrected hypercalcemia at $2.66 \mathrm{mmol} / 1$ was found. Hypercalcemia is a circumstance in the diagnosis of multiple Myeloma in almost $20 \%$ of cases. It is not a criterion of poor prognosis in itself because only very rare patients have a vital prognosis actually involved by this complication. It induces dehydration by polyurea polydipsea syndrome and finally, the appearance of renal failure. The impairment of renal function present in approximately $50 \%$ of patients diagnosed.
Varying degrees were not found in our patient [4]. In 99\% of patients, multiple myeloma appears to be a situation of hyper-secretion and over-production of a monoclonal immunoglobulin in the blood, whether or not associated with the detection of light chains in the urine (Bence Jones proteinuria) [1]. However, there was no peak in this specific case. And immunization of urinary proteins revealed the presence of $\kappa$ - like Bence-Jones protein. Myeloma imaging is often performed in the presence of complications that may be indicative of the disease [14]. Our patient presented a pathological fracture of the humeral shaft on conventional $\mathrm{x}$ ray that was associated with circular punched-out lytic images. The lytic images had no border of peripheral condensation of the cranial vault, maxilla and mandible at maxillofacial ct-scan. Usually these radiological manifestations are represented by multilacunar (13\%), osteopenia images $(6 \%)$, with focal lytic lesions possibly associated with fractures $(22 \%)$, association of the first three forms $(57 \%)$ or normal appearance $(21 \%)$ [2]. In our diagnosis, the recommended consensus MRI by the IMWG (International Myeloma Working Group) 2009 was not done in our work context [4]. It has the advantage of being very precise in cases of suspected spinal compression or neurological compression. It also has an important added value on the evaluation of the therapeutic response even if lesions can persist for a long time in a patient with an excellent therapeutic response [14]. According to Kyle et al. [3], the diagnosis of Myeloma is made by the presence of the following three criteria:

1. Spinal clonal plasma cells $\geq 10 \%$

2. Presence of a serum or urinary monoclonal immunoglobulin (except in the case of non-secreting multiple myeloma)

3. Presence of target organ damage due to plasma cell proliferation, defined by the presence of at least one CRAB criterion.

The bone marrow aspiration is a decisive step in the diagnostic process for multiple Myeloma. Bone marrow aspiration has highlighted an abnormal plasmocyte infiltration quantitatively and qualitatively. Plasma cell infiltration greater than $30 \%$ constitutes a major diagnostic criterion whereas plasmacytosis between 10 to $30 \%$ constitutes a minor criterion according to the diagnostic criteria of SWOG (South West Oncology Group) but other criteria were established in 2009 by the IMWG consensus [15]. Those are the CRAB criteria, independent of clinical symptomatology. They define organic damage due to the disease $[3,4]$ :

1. C for hypercalcemia ( $\geq 115 \mathrm{mg} / \mathrm{L}$ or $\geq 2.65 \mathrm{mmol} / \mathrm{L})$;

2. $\mathrm{R}$ for renal failure (serum creatinine $>173 \mu \mathrm{mol} / \mathrm{L}$ or $>$ $20 \mathrm{mg} / \mathrm{L}$ );

3. A for anemia (hemoglobin level $<10 \mathrm{~g} / \mathrm{dL}$ or more than $2 \mathrm{~g} / \mathrm{dL}$ below the lower limit of normal);

4. B for bone lesions (Bone lesions) (at least one lytic lesion, severe osteopenia or pathological fracture). Spinal histology is only necessary in the case of a negative myelogram as done in this observation [2]. It 
has revealed pathological plasma cell proliferation. The IMWG (2009) defined prognostic parameters to be analyzed at the time of diagnosis [4]. Treatment usually involves corticosteroid therapy, biphosphonates, chemotherapy, and hematopoietic sternal cell transplantation. But the prognosis remains poor with a survival average less than four years $[1,16]$. Our patient received Biphosphonate and pain reliever. She did not receive appropriate treatment for her illness due to the unavailability of molecules on site (Melphalan, velcade, thalidomide) and financial reasons. The death occurred six months later before he could benefit from an invasive treatment protocol given his relatively young age (less than 65 years). This invasive treatment included the bone marrow transplantation associated with new induction, consolidation and maintenance agents. The benchmark induction therapy has better efficacy / tolerance combines VTD (bortezomib, thalidomide and dexamethasone) [4].

\section{Conclusion}

Through this observation we retain that acute otitis media although frequent and can sometime be easily treated with antibiotics should not be trivialized. It can evolve and be complicated or be a circumstance of discovery of a general and potentially serious disease such as multiple myeloma. Hence, a rigorous clinical examination must be conducted.

\section{Declaration of Interests}

The authors declare that they have no conflicts of interest for this case study.

\section{References}

[1] Kamal D., Benhalima H., Kerrary S., Boulaich M., Kzadri M. Tumeur maxillaire révélatrice d'un myélome multiple: à propos d'un cas. Actualités Odonto-Stomatologiques 2012; 257: 57-61.

[2] Pittet-Barbier L., Coulomb M. Atteintes osseuses dans le myélome. Encycl Méd Chir (Editions Scientifiques et Médicales Elsevier SAS, Paris, tous droits réservés), Radiodiagnostic - Neuroradiologie-Appareil locomoteur, 31192-D-10, 2003, 14 p.
[3] Fouquet G., Guidez S., Herbaux C., Demarquette H., Leleu X. Myélome multiple indolent. La Revue de médecine interne 35 (2014) 243-249.

[4] Manier S., Leleu X. Myélome multiple : diagnostic clinique et perspective de traitement. Recommandations de l'International Myeloma Working Group (IMWG). Immunoanalyse et biologie spécialisée 2011; 26: 125-136.

[5] Ouédraogo P V., Boudzoumou B. D. E., Nahantchi A., Ndiaye M. Un infarctus cérébral révélant un myélome multiple. NPG Neurologie - Psychiatrie - Gériatrie 2018; 18: 170-173.

[6] Renou F., Gerber A., Moiton M P., Ferrandiz D., Yvin J L. Arthrite à pneumocoque révélant un myélome. La Revue de médecine interne 2007; 28: 186-187.

[7] Dougé A., Lemal R, Chaleteix C. Pomalidomide dans les myélomes multiples. Bull Cancer 2017; 104: 707-713.

[8] Lescanne E., Lanotte P., Pondaven S., Autret-Leca E. Otites moyennes aiguës. EMC (Elsevier Masson SAS, Paris), Otorhino-laryngologie, 20-085-A-10, 2006.

[9] Sarkis G., El Hachem N. L'otite moyenne aiguë, séreuse ou récidivante : l'avis du pédiatre. Kinesither Rev 2012; 12 (132): 12-7.

[10] Jahidi A., Zalagh M., Errami N., Akhiri M, Benariba F. Conduite à tenir devant une otite moyenne aigue. Espérance Médicale 2010; 17 (174): 667-72.

[11] Manier S., de la Contrie M C, Hieulle J., Daniel A., Facon T. Myélome multiple : des critères diagnostiques et pronostiques renouvelés et de forts espoirs thérapeutiques. Presse Med. 2019; 48: 825-831.

[12] Bouvarda B., Royer M., Chappard D., Audran M., Hoppé E., Legrand E. Gammapathie monoclonale de signification indéterminée, myélome multiple et ostéoporose. Revue du rhumatisme 2010; 77: 144-148.

[13] Debiais F., Vix J., Durand G., Azaïs I. Prise en charge des lésions osseuses du myélome multiple : quelles particularités ? Revue du rhumatisme monographies 2017; 84: 197-204.

[14] Touzeau C., Moreau P. Multiple myeloma imaging. Diagnostic and Interventional Imaging $2013 ; 94$ (2): 190-92.

[15] Bouatay A., Hizem S., Ben Youssef Y., Sayari F., Braham N., Khélif A., Kortas M. Myélome multiple : aspect clinique, diagnostic biologique et pronostic. Immuno-analyse et biologie spécialisée 2013; 28: 30-35.

[16] Vincent H., Chaïbi P. Traitement du myélome du sujet âgé : intérêt des nouvelles molécules. NPG Neurologie - Psychiatrie - Gériatrie 2008; 8: 10-18. 